\title{
Beta Samati: discovery and excavation of an Aksumite town
}

Michael J. Harrower ${ }^{1, *}$, Ioana A. Dumitru ${ }^{1}$, Cinzia Perlingieri ${ }^{2}$, Smiti Nathan ${ }^{3}$, Kifle Zerue ${ }^{4}$, Jessica L. Lamont ${ }^{5}$, Alessandro Bausi ${ }^{6}$, Jennifer L. Swerida ${ }^{7}$, Jacob L. Bongers ${ }^{8}$, Helina S. Woldekiros ${ }^{9}$, Laurel A. Poolman ${ }^{1}$, Christie M. Pohl ${ }^{10}$, Steven A. Brandt ${ }^{11}$ \& Elizabeth A. Peterson ${ }^{12}$

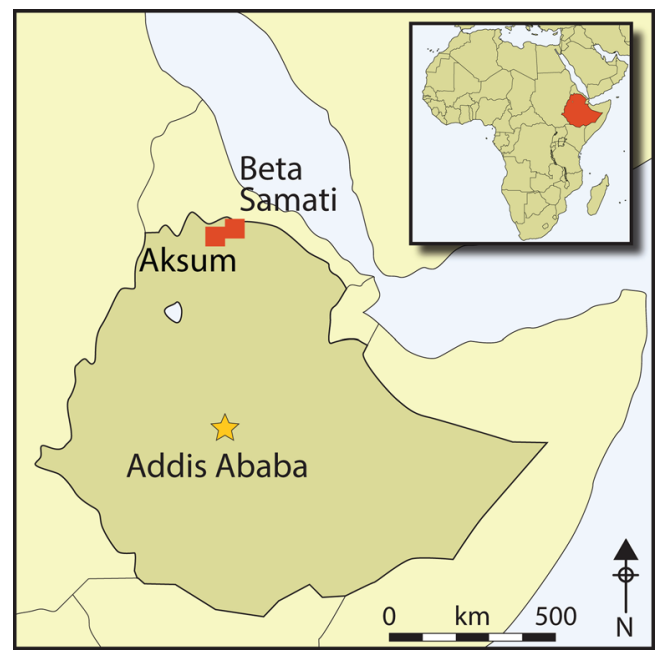

The Empire of Aksum was one of Africa's most influential ancient civilisations. Traditionally, most archaeological fieldwork has focused on the capital city of Aksum, but recent research at the site of Beta Samati has investigated a contemporaneous trade and religious centre located between Aksum and the Red Sea. The authors outline the discovery of the site and present important finds from the initial excavations, including an early basilica, inscriptions and a gold intaglio ring. From daily life and ritual praxis to international trade, this work illuminates the role of Beta Samati as an administrative centre and its significance within the wider Aksumite world.

Keywords: Africa, Ethiopia, Aksum, ancient trade, ancient states

1 Department of Near Eastern Studies, Johns Hopkins University, Gilman 113, 3400 North Charles Street, Baltimore, $M D$ 21218, USA

2 Center for Digital Archaeology, 555 Northgate \#270, San Rafael, CA 94903, USA

3 Life Design Lab, Johns Hopkins University, 3400 North Charles Street, Baltimore, MD 21218, USA

4 Archaeology and Heritage Management, P.O. Box 1010, Aksum University, Aksum, Ethiopia

5 Department of Classics, Yale University, 344 College Street, P.O. Box 208266, New Haven, CT 06520, USA

6 Asien-Afrika-Institut, Universität Hamburg, Edmund-Siemers-Allee 1, Flügel Ost, 20146 Hamburg, Germany

7 Department of History and Archaeology, American University of Beirut, P.O. Box 11-0236, Riad El-Sohl, Beirut 1107 2020, Lebanon

8 Sainsbury Research Unit, University of East Anglia, Norwich NR4 7TJ, UK

9 Department of Anthropology, Washington University in St Louis, Campus Box 1114, One Brookings Drive, St Louis, MO 63130, USA

10 Museum of Fine Arts, Boston, 465 Huntington Avenue, Boston, MA 02115, USA

11 Department of Anthropology, University of Florida, Turlington 1112, P.O. Box 117305, Gainesville, FL 32611, USA

12 Department of Archaeology, Simon Fraser University, 8888 University Drive, Burnaby, BC V5A 1S6, Canada

* Author for correspondence (Email: mharrower@jhu.edu)

(C) Antiquity Publications Ltd, 2019. This is an Open Access article, distributed under the terms of the Creative Commons Attribution licence (http://creativecommons.org/licenses/by/4.0/), which permits unrestricted re-use, distribution, and reproduction in any medium, provided the original work is properly cited.

ANTIQUITY 93372 (2019): 1534-1552

https://doi.org/10.15184/aqy.2019.84 


\section{Introduction}

In 2009, the Southern Red Sea Archaeological Histories (SRSAH) Project began survey of a $100 \mathrm{~km}^{2}$ region surrounding the town of Yeha in northern Ethiopia. Home to the oldest standing architecture and earliest writing in sub-Saharan Africa, Yeha is often proposed as the capital of a Pre-Aksumite state of the early first millennium BC (cf. Phillipson 2012: 38-40). Archaeological survey in the 1970s documented numerous important sites near Yeha (Anfray 1973; Michels 2005), but the wider surrounding area remained underexplored, and was presumed to have been abandoned by political authorities after the Pre-Aksumite period (Fattovich 2010: 165). Information from local residents led the SRSAH Project to Beta Samati, a 20ha settlement featuring a 14 ha central tell that stands up to $25 \mathrm{~m}$ above the surrounding valley (Figure 1). Excavations in 2011, 2012, 2015 and 2016 revealed stone architecture extending more than $3 \mathrm{~m}$ below the ground's surface, dating to as early as the eighth century $\mathrm{BC}$, and a basilica built during the fourth century AD. The latest occupation of the site dates to the seventh century AD.

The recent discovery of Beta Samati is of considerable importance for understanding the development of early complex polities in Africa (Table 1). Our work demonstrates that Beta Samati was a large, densely populated settlement located $6.5 \mathrm{~km}$ (90 minutes by foot) northeast of Yeha, the centre of political power for sub-Saharan Africa's earliest (Pre-Aksumite) complex polity. Our findings also demonstrate that, contrary to the supposed abandonment of the Yeha region following the Pre-Aksumite period, Beta Samati continued to function as a major node on trade routes that linked the Mediterranean to Adulis and Aksum during the Classic, Middle and Late Aksumite periods.

\section{Archaeological background}

A considerable body of research has established crucial details (e.g. Finneran 2007; Schmidt et al. 2008; Phillipson 2012; Fattovich 2018), but Aksum remains one of the least documented major civilisations of the ancient world. Ethiopia's earliest complex polities appeared during the Pre-Aksumite period ( $c$. eighth century BC), as indicated by a settlement pattern of towns, villages and hamlets, with a major ceremonial centre at Yeha. Although monumental architecture, iconography and writing provide clear evidence for cultural links between northern Ethiopia and South Arabia (Gerlach 2012; Breton 2015), most scholars explain PreAksumite civilisation as a largely endogenous phenomenon (Manzo 2009; Fattovich 2010; Phillipson 2012). By the Early Aksumite period, the Kingdom of Aksum ruled a rapidly expanding population (Fattovich 2018).

Long-distance trade contributed to Aksum's social and economic complexity, and helped to consolidate political power (e.g. Manzo 2005). Monumental tombs topped with stelae were erected for kings, with smaller standing stones marking the graves of elites. At its peak, during the third to sixth centuries AD, the Empire of Aksum launched military campaigns that periodically extended its dominion into Yemen (Hatke 2012) and intermittently subdued parts of Sudan to claim Kush (perhaps overstatedly) as a vassal state (Hatke 2013: 67-82). During Aksum's apogee, state business was administered from palatial compounds, such as those at Dungur near Aksum (Anfray 2012a). Beyond the capital of Aksum, the excavation of sites

(C) Antiquity Publications Ltd, 2019 


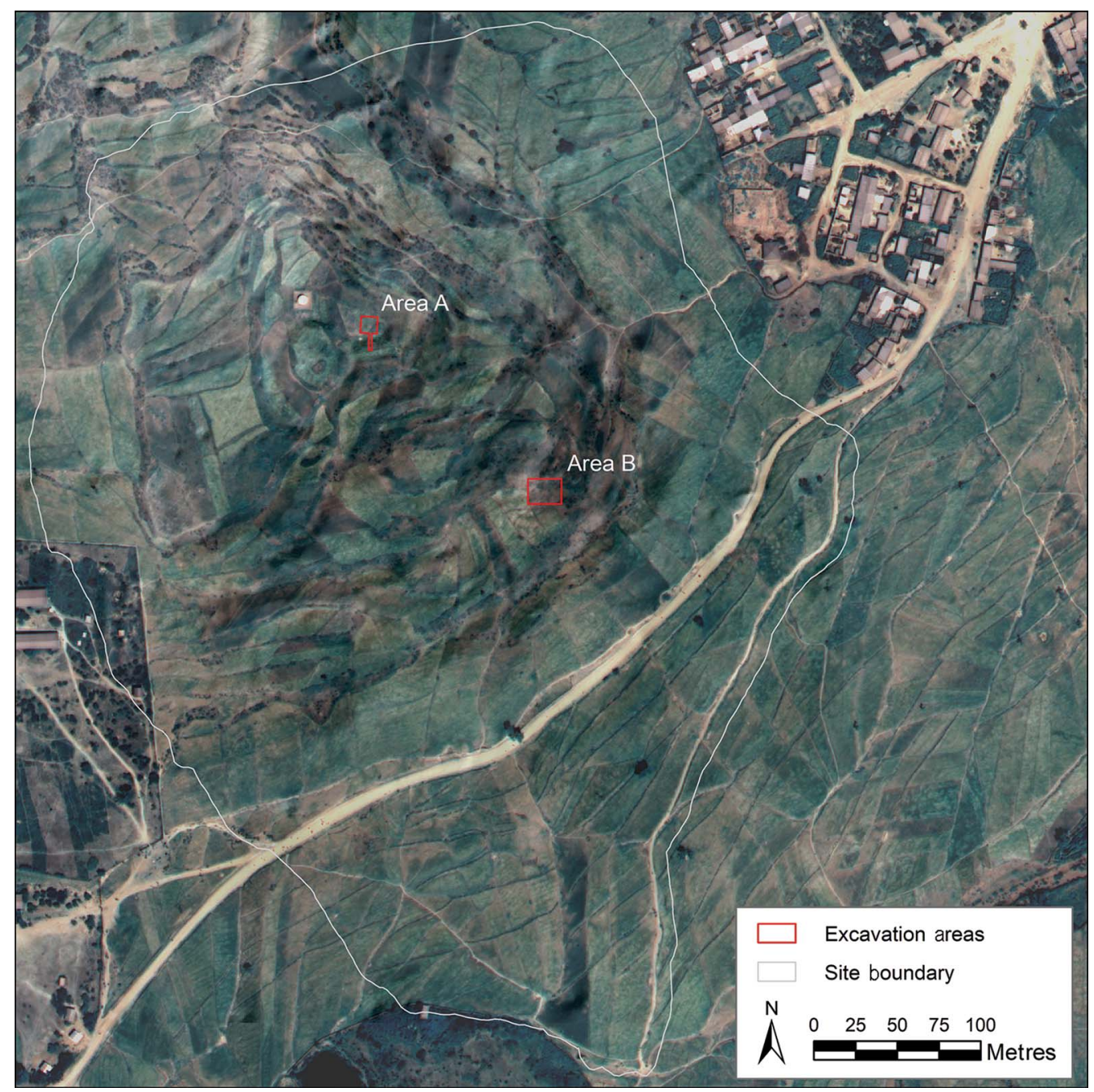

Figure 1. Map of Beta Samati from Worldview-3 satellite imagery, overlaid on a $5 m$ DEM of terrain from ALOS PRISM satellite imagery (figure by M. Harrower).

including Matara in Eritrea (1959-1964) have clarified regional cultural links and trade connections (Anfray 2012b). During the mid fourth century AD, King Ezana converted Aksum to Christianity, but the early impacts of royal conversion on the non-elite populace are not well understood. The Late Aksumite period is of considerable significance as it coincides with the rise of Islam. In AD 615, the King of Aksum (possibly King Armah, see below) granted refuge to early Muslims, including one of the Prophet Mohammed's daughters, and his son-in-law/ successor 'Uthman Ibn 'Affan and compatriots (van Donzel \& Schoeler 2007: 30-32). While Aksum was spared the initial conquest of Islam, its decline has long been presumed to relate, in part, to the loss of control over Red Sea trade (Phillipson 2012: 210). 
Table 1. Chronology for the Empire of Aksum and its precursors from Bard et al.'s (2014) Bayesian analysis of radiocarbon dates from excavations of Beta Giyorgis, Aksum, which provides the most recent and rigorously quantitative sequence available.

\begin{tabular}{lc}
\hline Period & Date range \\
\hline & \\
Pre-Aksumite & $800-360$ BC \\
Proto-Aksumite & $360-80$ BC \\
Early Aksumite & 80 BC-AD 160 \\
Classic Aksumite & AD 160-380 \\
Middle Aksumite & AD 380-580 \\
Late Aksumite & AD 580-825 \\
Post-Aksumite & AD 825-900 \\
\hline
\end{tabular}

\section{Archaeological significance of the Yeha region}

Yeha is a site of wide archaeological significance, as it preserves important evidence regarding the earliest complex polities in sub-Saharan Africa. More than a century of sporadic archaeological investigations, beginning with the Deutsche Aksum Expedition in 1906, have clarified Yeha's history, revealing the construction of a major temple during the seventh century BC. Built by a chiefdom or a state, the temple's architecture, iconography and inscriptions show clear South Arabian influences (Robin \& de Maigret 1998; Fattovich 2009; Gerlach 2012).

Despite Yeha's importance, earlier investigations focused on a relatively small area surrounding the site's monuments and tombs, leaving a critical shortfall in information concerning the wider region. Prior to our survey, investigations of the Yeha region had been rare. In the 1960s and 1970s, Anfray (1973: 17-19, 1990:32-33) led a team that recorded a number of important sites close to Yeha. Michels's (2005) team surveyed a $714 \mathrm{~km}^{2}$ region between Aksum and Yeha in 1974, although this work extended only a kilometre beyond Yeha (Michels 2005: 1-8). Given the paucity of Aksumite-period sites initially identified, the Yeha area was long thought to have been vacated by political authorities after the PreAksumite period (Fattovich 2009, 2010: 165). This notion of abandonment, however, has recently been overturned by results of the SRSAH survey, which documented 84 sites in the region around Yeha (Harrower et al. in press). One of the most important of these sites - the town of Beta Samati-forms the focus of the present paper, which summarises the results of four seasons of excavation between 2011 and 2016.

\section{The site of Beta Samati}

The ancient town of Beta Samati, or 'Betä Säma 'ti', meaning 'house of audience' in the local Tigrinya language, was first identified in 2009 after enquiries with local residents led SRSAH researchers to investigate a hill near the modern village of Edaga Rabu. Excavations, launched two years later, have revealed small-stone, mud-mortar structures extending to depths of at least $3 \mathrm{~m}$ in two areas (excavations have yet to reach strata devoid of cultural material). Mounds of stone debris on the surface suggest that stone-walled structures probably extend

(C) Antiquity Publications Ltd, 2019 


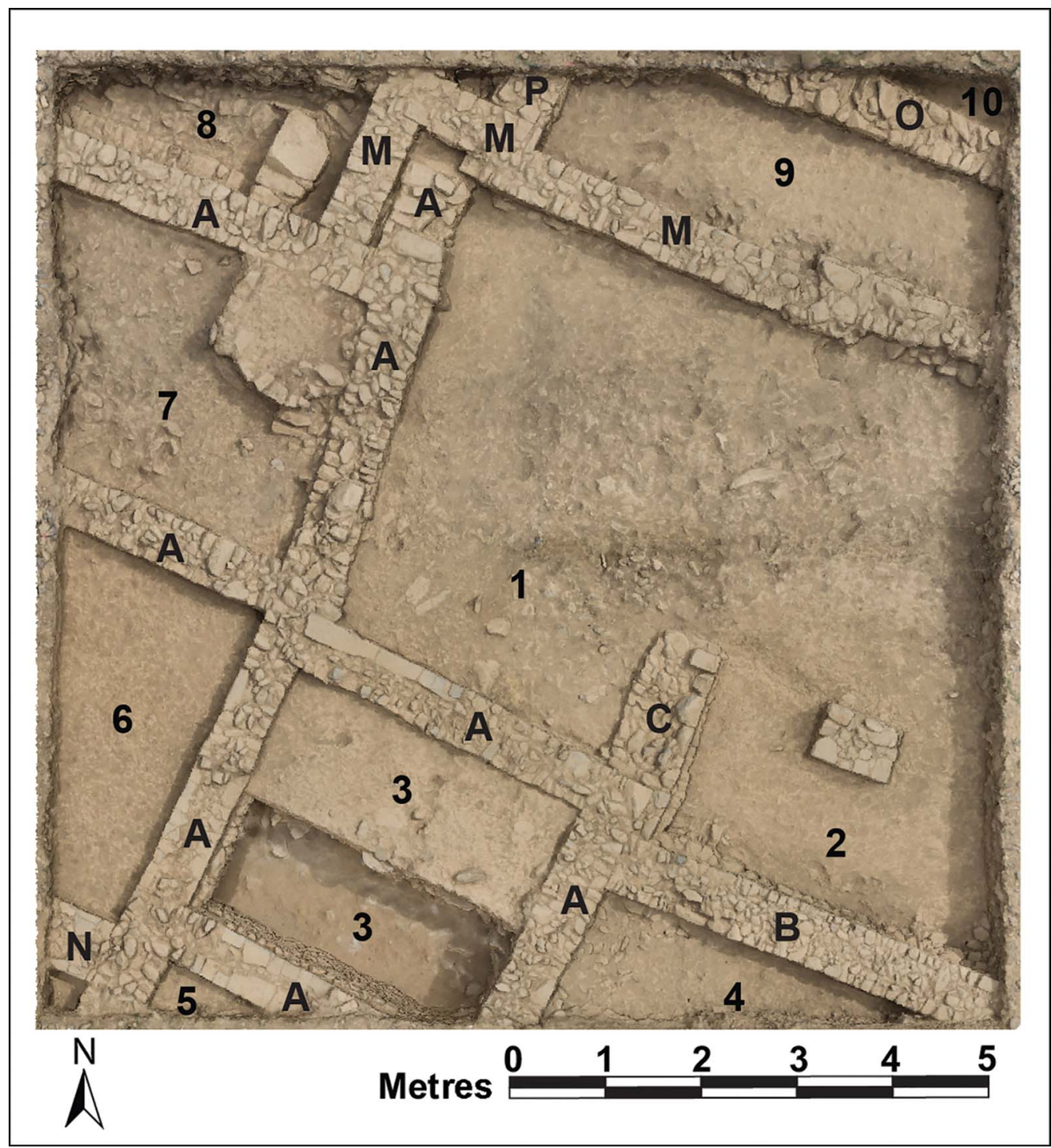

Figure 2. Plan of area A from a $3 D$ model (2015). Walls are designated with letters, and spaces (including rooms) designated with numbers. Wall $A$ represents an earlier building phase, followed by walls $B, C, M, N$ and $P$ (figure by J. Mazzariello).

across the entire 14 ha central tell. In 2011 , a $2 \times 6 \mathrm{~m}$ test trench near the top of the tell revealed stone architecture immediately below the plough zone. In 2012, this trench, designated 'area A' (Figure 1), was expanded to $2 \times 15 \mathrm{~m}$. A further $2 \times 15 \mathrm{~m}$ trench was opened closer to the base of the hill, labelled 'area B', where local farmers had reported the presence of massive hewn blocks of sandstone. In 2015, our excavations expanded previous trenches to $10 \times 10 \mathrm{~m}$ in both areas A (Figure 2) and B, to gain better understanding of the site's layout. In 2016 , area $B$ was expanded to $15 \times 20 \mathrm{~m}$, revealing the complete layout of an ancient basilica (Figure 3).

(C) Antiquity Publications Ltd, 2019 


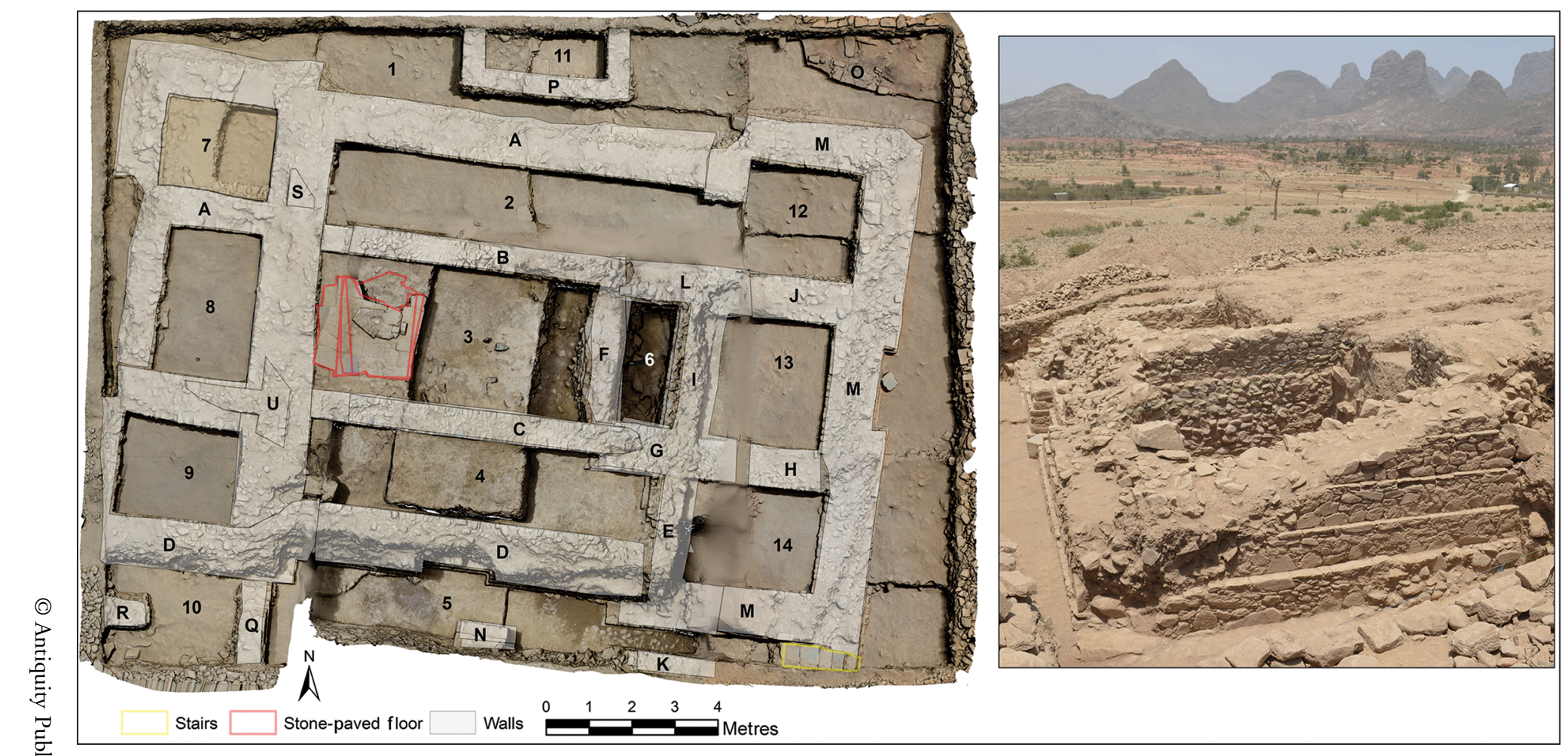

Figure 3. Plan of the area B basilica created from a 3D model of the 2015 and 2016 excavations. Walls are designated with letters, and spaces (including rooms) designated with numbers. Walls $K, M, N, G, I, J$ and $L$ represent an earlier building phase; wall $A$, along with walls $B, C, D$ and $F$ represent a later phase. Photograph (right) is taken from the $\vec{\rho}$ north-east corner, looking south (figure by C. Hickman, M. Harrower \& J. Mazzariello).

\section{Research}


Table 2. Radiocarbon dates from Beta Samati (all dates calibrated with OxCal 4.3 and IntCal 13; Bronk Ramsey 2009; Reimer et al. 2013).

\begin{tabular}{|c|c|c|c|c|c|c|c|c|c|}
\hline \# & Year & Area & Locus & Lot & Bag & Lab code & Material & $\begin{array}{c}\text { Radiocarbon } \\
\text { years BP }\end{array}$ & $\begin{array}{c}\text { Calibration } \\
(95.4 \%)\end{array}$ \\
\hline 1 & 2012 & A & 20 & 3 & 3 & $\begin{array}{c}\text { D-AMS } \\
20959\end{array}$ & $\begin{array}{l}\text { Triticum cf. } \\
\text { dicoccum }\end{array}$ & $2477 \pm 27 \mathrm{BP}$ & $771-485 \mathrm{BC}$ \\
\hline 2 & 2012 & A & 20 & 4 & 5 & $\begin{array}{c}\text { D-AMS } \\
22060\end{array}$ & Poaceae & $2425 \pm 39 \mathrm{BP}$ & $752-403 \mathrm{BC}$ \\
\hline 3 & 2015 & B & 45 & 2 & 16 & $\begin{array}{c}\text { D-AMS } \\
20961\end{array}$ & $\begin{array}{l}\text { Triticum cf. } \\
\text { dicoccum }\end{array}$ & $1674 \pm 30 \mathrm{BP}$ & AD 258-425 \\
\hline 4 & 2015 & B & 50 & 1 & 5 & $\begin{array}{c}\text { D-AMS } \\
20960\end{array}$ & $\begin{array}{r}\text { Hordeum } \\
\text { vulgare }\end{array}$ & $1655 \pm 25 \mathrm{BP}$ & AD 332-506 \\
\hline 5 & 2011 & A & 11 & 2 & 7 & $\begin{array}{c}\text { BETA } \\
317411\end{array}$ & Wood charcoal & $1500 \pm 30 \mathrm{BP}$ & AD 432-639 \\
\hline 6 & 2012 & B & 1 & 1 & 45 & $\begin{array}{c}\text { BETA } \\
391883\end{array}$ & Wood charcoal & $1480 \pm 30 \mathrm{BP}$ & AD 538-645 \\
\hline
\end{tabular}

In terms of dating, the earliest current evidence for occupations in area $\mathrm{A}$ is indicated by Pre-Aksumite ceramics, which were found in direct association with two stratigraphically superimposed radiocarbon-dated seeds from the lowest excavated layers (Table 2: 1-2). In area $B$, the dating of two stratigraphically superimposed domesticated seeds from space 6 places the earliest use of the Beta Samati basilica in the fourth century AD (Table 2:3-4). Two final radiocarbon assays on wood charcoal date the latest stages of habitation at Beta Samati to as late as the mid seventh century AD (Table 2: 5-6).

\section{Excavation methods}

Our field strategy integrated the excavation of loci (stratigraphic layers) and lots (arbitrary subdivisions) and the screening of soil through a $6.5 \mathrm{~mm}$ mesh. A Trimble GPS base station and rovers were used to provide centimetre-accurate mapping. This system enabled the recording of vector data (points, lines and polygons) with a custom data dictionary so that attribute data were easily transferred to a geographic information system (GIS). Photographs and GPS data were processed with ArcMap, ArcScene, Agisoft PhotoScan and Reality Capture software to create 2D and 3D maps. In 2015, we adopted a customised version of the database Codifi, designed by the Center for Digital Archaeology (now Codifi Inc.). Excavation records and images were collected in the field using iPads, and artefact analyses were recorded in the laboratory using laptops and iPads. As numerous walls extend into unexcavated areas, it was impossible to determine whether these formed rooms; hence, we use the term 'space' to designate localities defined by walls.

\section{Excavation results}

Excavations of Beta Samati have revealed a residential or workshop precinct in area A, and a basilica in area B. Our investigations clarify the chronology and spatial layout of Beta Samati, and have yielded evidence of trade, administration and religious activities.

(C) Antiquity Publications Ltd, 2019 
Area $A$

Area A contains a complex of rectangular stone structures. Evidence for food preparation, small-scale metal and glass production, pack animals and coinage indicate both domestic and workshop activities, along with engagement in commercial activities. Importantly, architectural planning is indicated by the construction of a long wall (wall A), comprised of interlocking segments that were built in a single phase to create a series of adjoining rooms and spaces. From the upper to lower strata, the ceramic assemblage primarily consists of undecorated utilitarian grey/black and brown/buff Late Aksumite wares, a lower quantity of orange/ red Middle Aksumite wares, often decorated with incised patterns, and a few Classic Aksumite and Pre-Aksumite sherds from the lowest layers. Utilitarian pottery, large quantities of grinding stones and small storage caches indicate food storage, preparation and consumption.

Differences in the distribution of pottery forms across area A provide information regarding the use of different spaces. A higher percentage of jars, large collared bowls, small cups and small bowls in space 1-perhaps an outdoor or courtyard area-suggests activities related to storage or consumption of food. In space 4, a large assemblage of fragmented, Middle Aksumite open and closed bowls, bottles, cauldrons and a mogogo griddle (cf. Lyons 2007), found atop a matrix of burnt bone fragments and significant quantities of charcoal and ash, indicates cooking and food consumption. In a higher stratum of space 4, a large boulder with a flat upper surface, perhaps used as an anvil, was found in association with metal slag and glass wasters, suggesting the later use of this area for metal- and glass-working.

The age of the latest occupations in area A are indicated by Middle/Late Aksumite pottery, and a radiocarbon assay on wood charcoal from immediately beneath wall $A$ that calibrates to

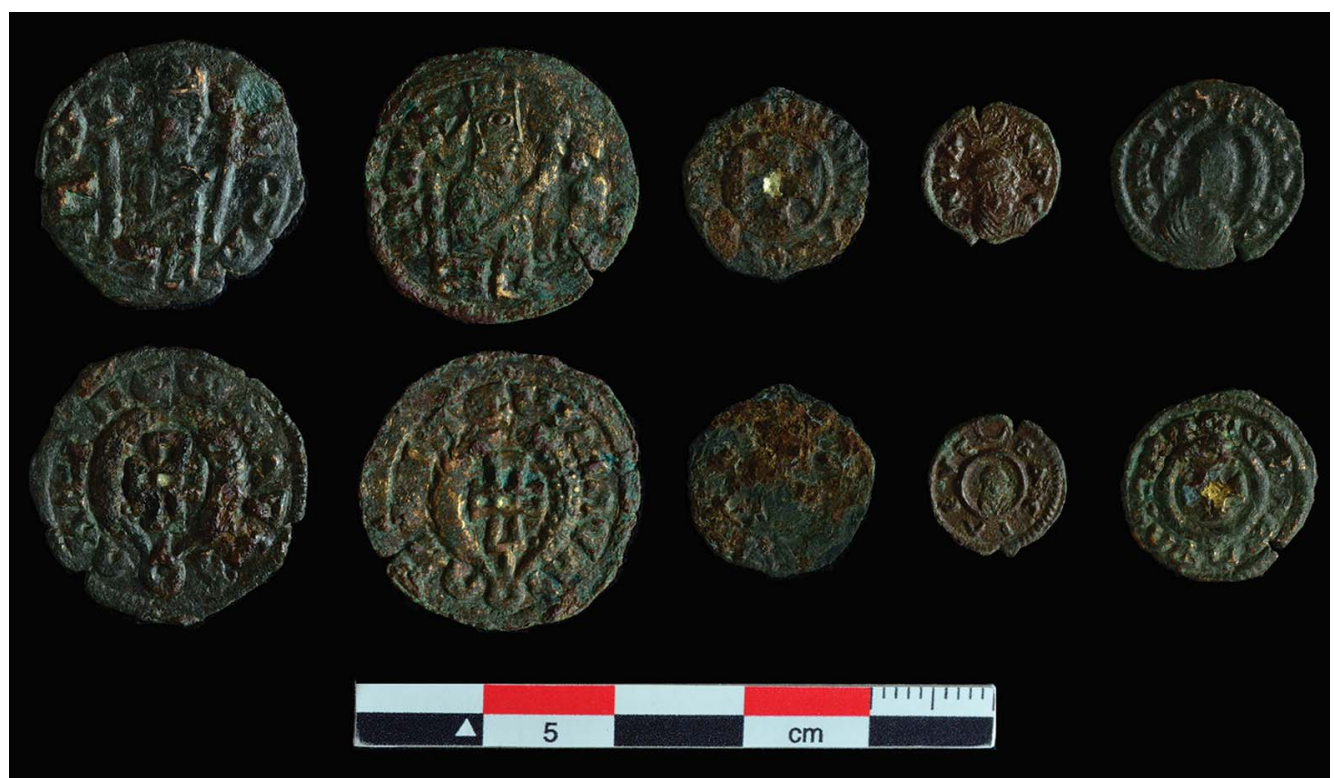

Figure 4. Coins from Beta Samati, from left to right: a) King Armah; b) King Armah; c) anonymous king; d) King Ezana; e) King MHDYS (figure by I. Dumitru).

(C) Antiquity Publications Ltd, 2019 


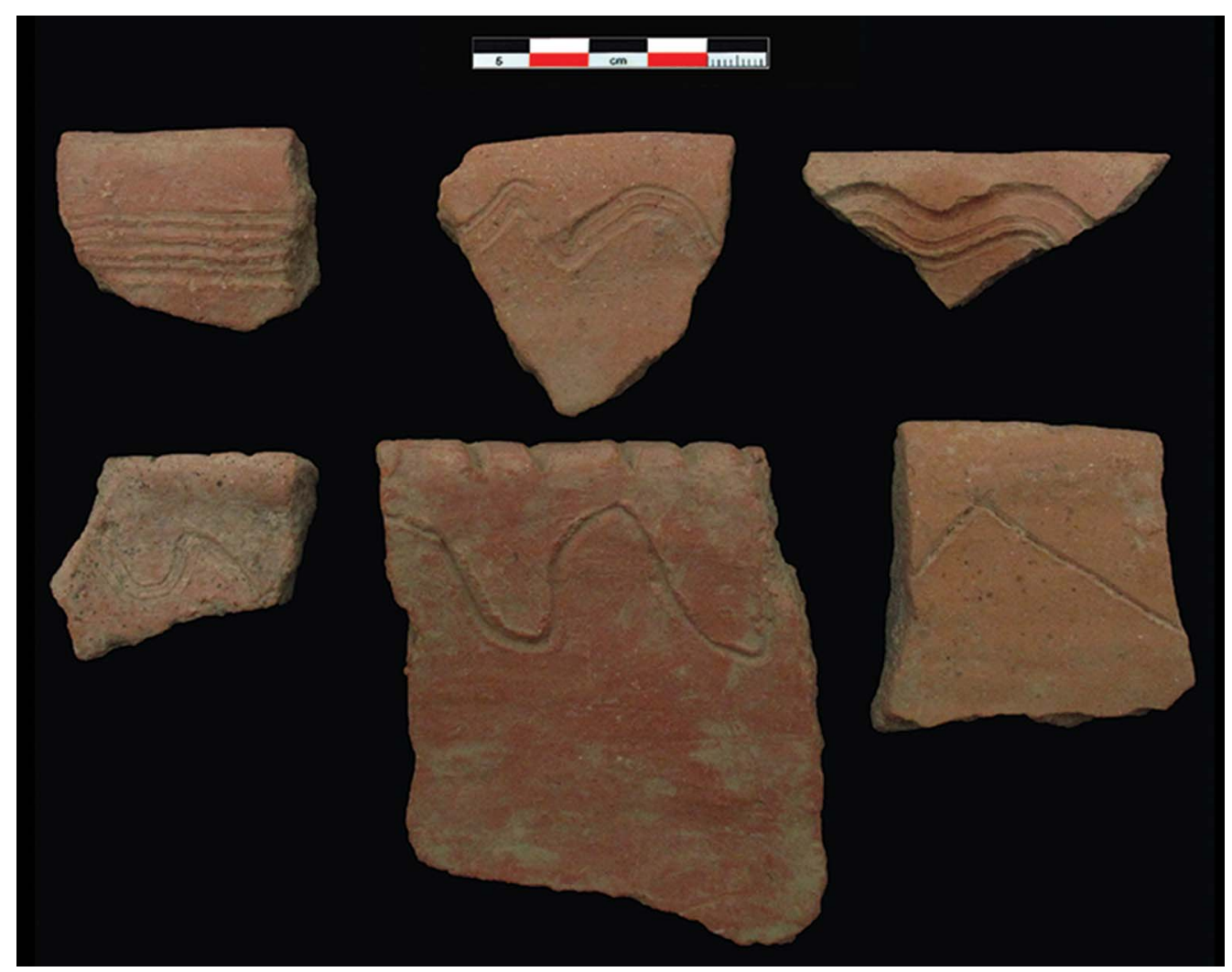

Figure 5. Incised wavy line pottery (figure by J. Swerida).

AD 432-639 (Table 2: 5). A bronze coin of King Armah dating to $c$. AD 600-630 found nearby (Figure 4a) suggests that the actual age of these deposits falls in the latter part of the radiocarbon date range (Munro-Hay \& Juel-Jensen 1995; Hahn's (2010) suggestion that King Armah should be dated to AD 540-580 is not yet widely accepted; see Bausi 2017: 102). Four additional coins were found in area A (space 4), including a bronze coin of King Armah identical in type to the former (Figure 4b), a bronze coin belonging to an anonymous king, possibly from the first half of the fifth century AD (Figure 4c), a preChristian silver coin of King Ezana (c. AD 300-330; Figure 4d) and a bronze coin of King MHDYS (c. AD 450; Figure 4e; Munro-Hay 1995). Although these coins exhibit a broad chronological distribution, the King Armah coins, together with the pottery and the radiocarbon date, indicate a Late Aksumite age for the uppermost layers of area A.

Stylistic characteristics of the pottery at Beta Samati also provide insights concerning regional traditions. Area A, for example, is characterised by a high incidence of incised wavy line motifs decorating utilitarian large open bowls (Figure 5). These wavy line motifs have traditionally been interpreted as being Pre-Aksumite, and are a defining feature of the contemporaneous Ancient Ona Culture of Eritrea (Fattovich 1980; Manzo 2003: 3839; D’Andrea et al. 2008a; Schmidt et al. 2008; Curtis 2009). This chronological attribution, which is supported by a dearth of incised wavy lines on ceramics from Aksumite layers at Beta

(C) Antiquity Publications Ltd, 2019 
Giyorgis (Aksum), however, does not necessarily preclude a greater longevity for this motif. In the stratigraphic sequence at Beta Samati, wavy line motifs are frequently associated with pottery types from Middle and Late Aksumite layers, such as ledge rim open bowls decorated with crosses. This suggests that the wavy line motif may not be a definitive marker of the PreAksumite, as it appears to have continued at Beta Samati into the Middle and Late Aksumite periods.

A sizable faunal assemblage from area A (number of identified specimens $($ NISP) $=2574$ ) attests to the presence of domesticates, including cattle (Bos taurus or indicus), sheep (Ovis aries), goats (Capra hircus), possible dik-dik (Neotragini), donkeys (Equus asinus), camels (Camelus dromedarius), cats (Felis catus) and chickens (Gallus gallus), along with wild birds, guinea fowl (Numidinae) and francolin (Francolinus sp.). Sheep and goats (63 per cent) were the most abundant fauna from area A, followed by cattle (34 per cent). The frequency of domestic caprine, cattle and chicken, supplemented with wild species (dik-dik and wild fowl), suggests that these species all served as significant sources of dietary protein. The relatively high proportion of sheep and goats differs from other Aksumite sites (as well as from the area $\mathrm{B}$ faunal assemblage), which tend to have much larger proportions of cattle. Transport animals, including camels $(\mathrm{NISP}=2)$ and donkeys $(\mathrm{NISP}=3)$, were represented by small numbers, which is consistent with their general scarcity in Aksumite archaeological contexts (Cain 2000; Chaix 2013).

Archaeobotanical analysis has identified copious charred Poaceae seeds, most notably t'ef (Eragrostis tef), wheat (Triticum dicoccum) and barley (Hordeum vulgare). T'ef is an economically important crop in modern-day Ethiopia, used to make flat bread called injera. Its antiquity, however, is poorly understood, as relatively few sites have thus far yielded evidence of its use in ancient times (D'Andrea 2008; D'Andrea et al. 2008b).

The area A excavations yielded 301 lithics, most of which are of quartz ( 49 per cent) or obsidian (43 per cent), followed by chert, chalcedony and basalt. The 14 cores are evenly split between non-obsidian single-/multi-platform examples, and obsidian bipolar cores. The debris ( 85 per cent) is dominated by direct percussion flakes, blades and fragments (52 per cent), but also includes small bipolar flakes/blades (17 per cent). The 20 shaped tools (7 per cent) include eight end or side scrapers, one $78 \mathrm{~mm}$-long basalt circular scraper, seven small obsidian backed pieces, including five crescents, and four obsidian outil ecailles.

\section{Area B}

The excavations of area B revealed a basilica with a rectangular, tripartite Syriac indented plan $(18.7 \times 12.4 \mathrm{~m})$, characterised by exterior recessed and rabbeted walls with projecting corners and dressed cornerstones emblematic of the Aksumite Christian tradition (Heldman 2003; Phillipson 2009). The layout is similar to the Middle to Late Aksumite basilicas at Aksum (Ricci \& Fattovich 1987; Hagos 2011), although the rectangular rather than apsidal sanctuary plan at Beta Samati suggests an earlier date (Di Salvo 2017: 25). The basilica shows evidence for ritual and administrative activities, international trade and preferential access to high-value foods. A Ge'ez (i.e. ancient Ethiopic) inscription (Figure 6) reads and translates as: 


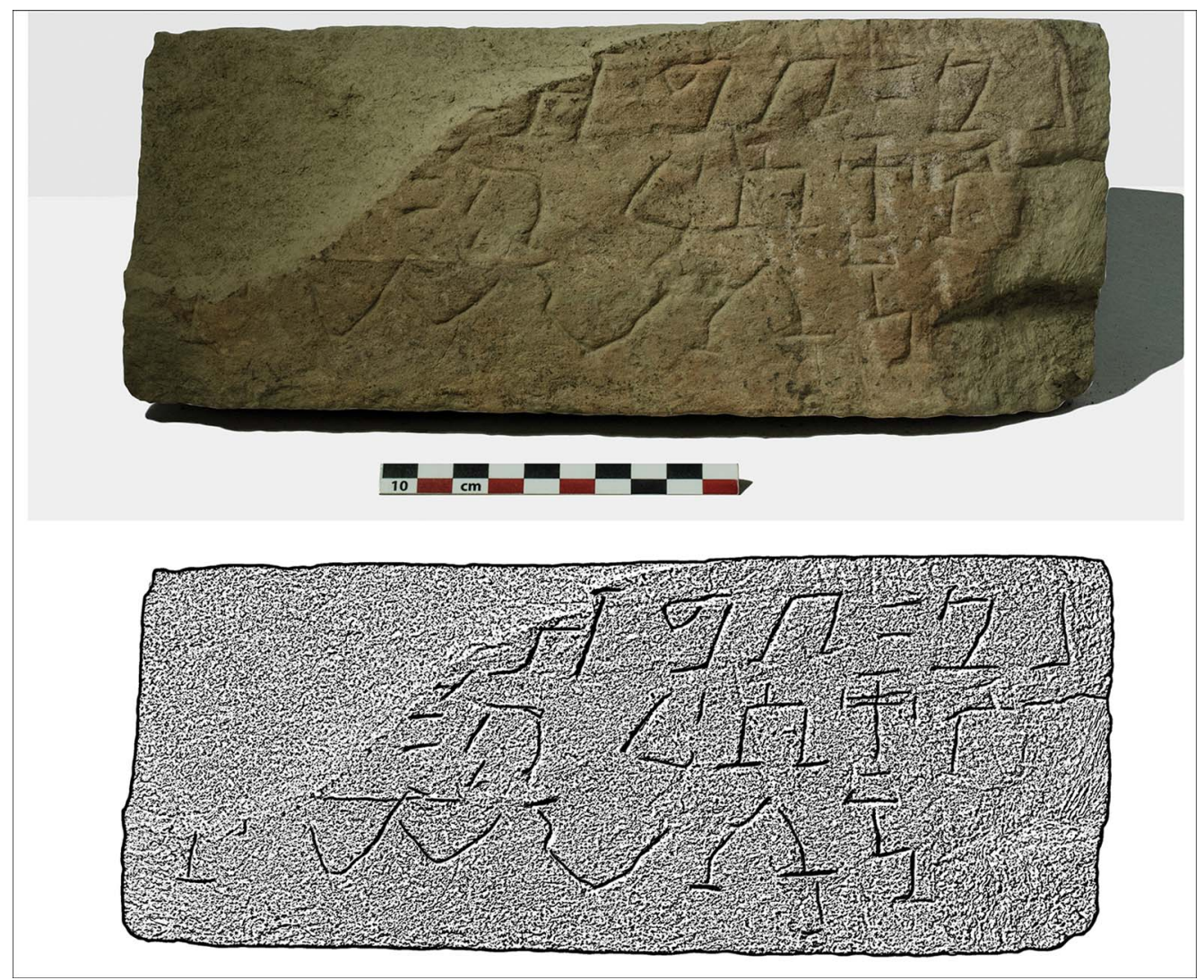

Figure 6. Ge'ez inscription found just outside the eastern basilica wall (figure by I. Dumitru).

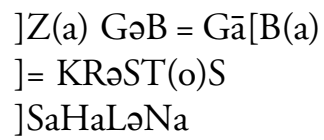

for/to] this entrance/atrium (or 'corvée': the term gabgāa is of debated interpretation)

] Christ

be] favourable to us

Middle to Late Aksumite pottery recovered from upper strata in area B and Classic Aksumite pottery retrieved from lower levels are consistent with radiocarbon assays (Table 2). At present, it is difficult to know whether prominent diagnostic styles identified at Beta Samati, such as Classic Aksumite decorations and Middle/Late Aksumite vessels with incised crosses on ledge rims, were locally produced or imported. Macroscopic examination, however, shows forms and fabrics very similar to vessels from Beta Giyorgis (Aksum), suggesting connections with the capital.

(C) Antiquity Publications Ltd, 2019 


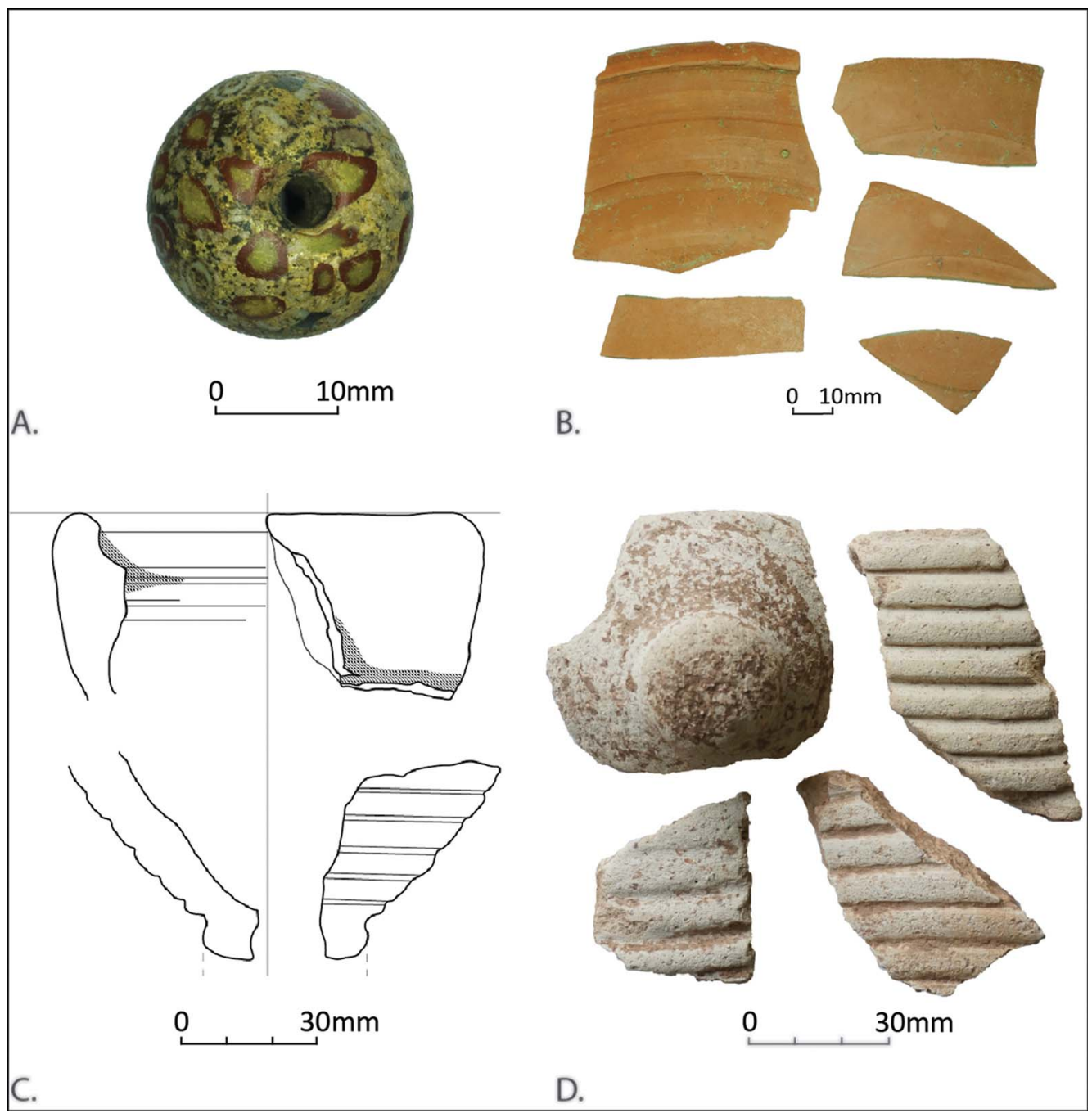

Figure 7. Artefacts illustrating long-distance trade: a) millefiori glass bead; b) terra sigillata (African red slip); $c-d$ ) Aqaba amphorae (figure by I. Dumitru \& C. Perlingieri).

Several artefact types found in area B, but not A, are important in that they reveal longdistance trade, including Aqaba (Ayla) amphorae $(\mathrm{n}=120)$, African red slip/terra sigillata $(\mathrm{n}=15)$, and a millefiori glass bead probably produced in the Eastern Mediterranean (Figure 7). Most significantly, the relatively high frequency of Aqaba amphorae in area B, even compared with the quantities found in elite contexts at Beta Giyorgis (Manzo 2005), indicates that Beta Samati was an important trade node, with access to amphorae (perhaps containing wine) traded from the Eastern Mediterranean to Adulis and then on to Aksum (Raith et al. 2013; Zazzaro 2013).

A range of objects offer insights into ritual and administrative activities (Figure 8) at Beta Samati, including incense burners $(n=105$, found only in area B), figurines and ceramic 


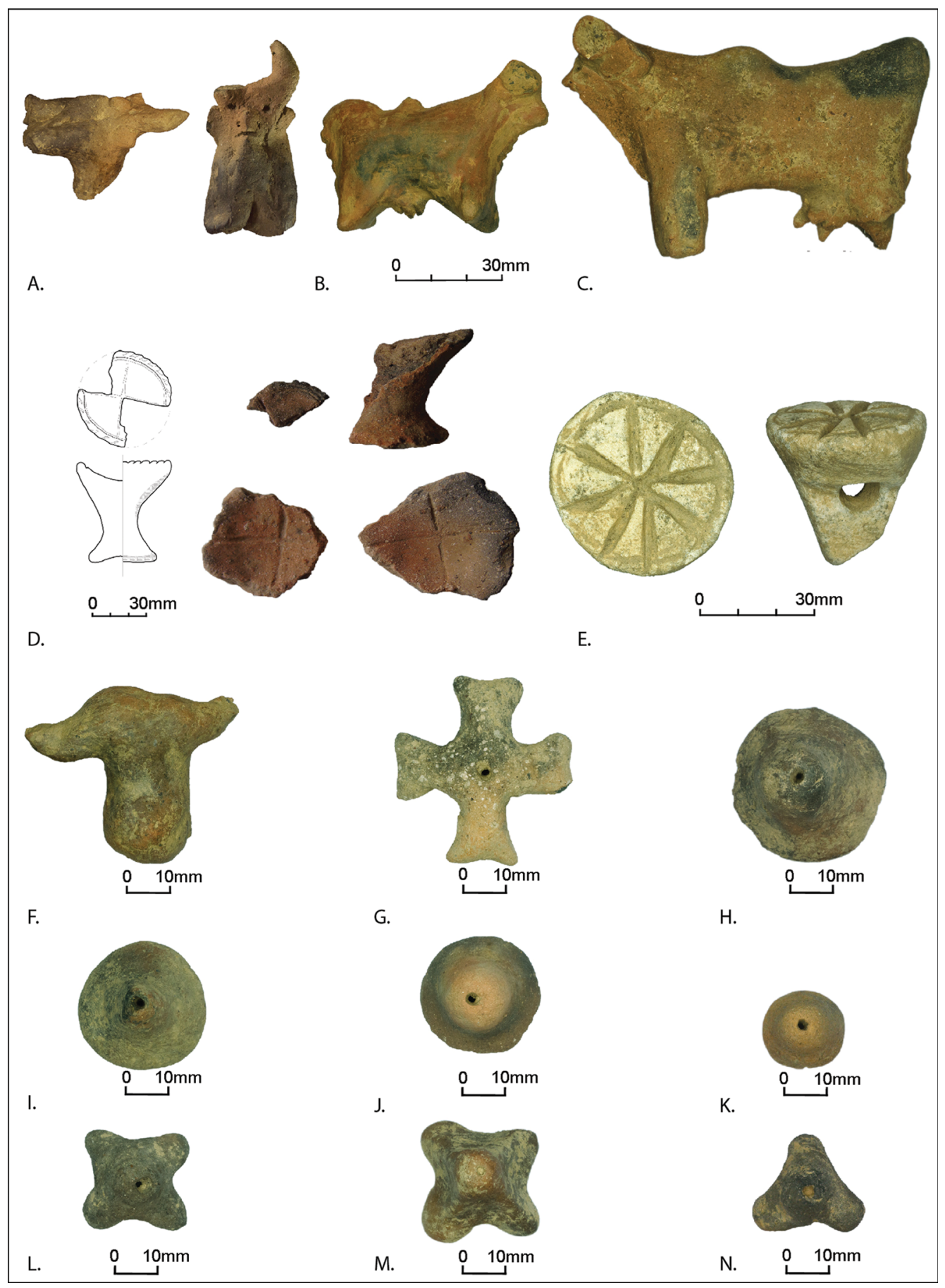

Figure 8. Artefacts illustrating ritual, administrative andlor trade activities at the basilica: a) bucranium with facial features; b-c) cow figurines; d) incense burners; e) stamp seal; f) bucranium; g-n) tokens (figure by I. Dumitru).

(C) Antiquity Publications Ltd, 2019 


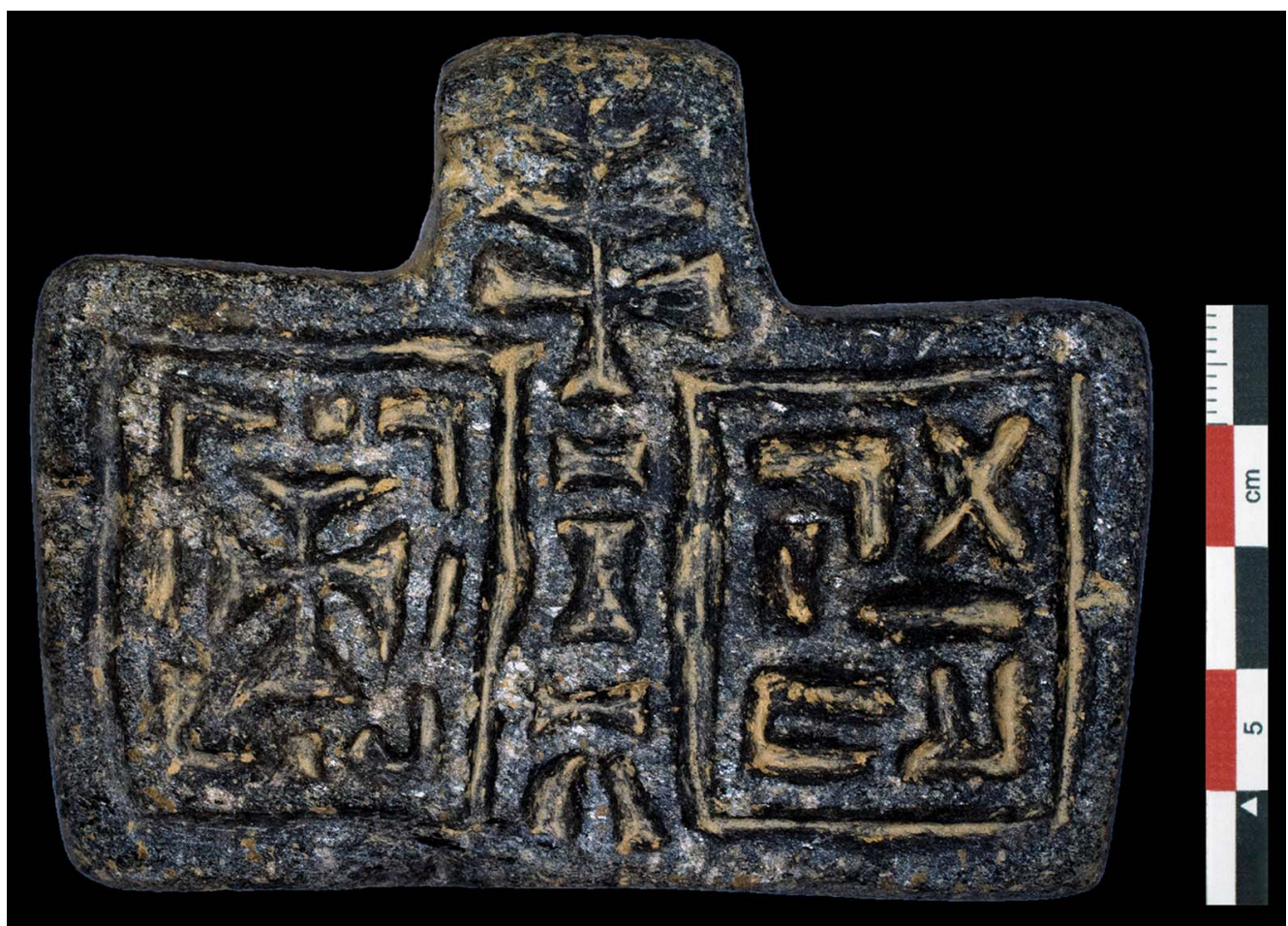

Figure 9. Stone pendant found just outside the eastern basilica wall (figure by I. Dumitru).

bucrania, stamp seals, and enigmatic small disc-, cone- and cross-shaped ceramic objects sometimes referred to as 'tokens' (Fattovich 2010: 155 \& 160). Others have described these so-called tokens as whorls, weights or simply as clay objects (Krencker 1913: 204, object 85; Anfray \& Annequin 1965: pl. LXV, fig 3, pl. LXVI, fig. 1; Phillipson 2000: 211-12). Although their exact purpose remains unknown, they lack the symmetry necessary to serve as spindle whorls. Many are pierced by a hole for stringing together, possibly suggesting a role in trade-related accounting, or administrative activities (Fattovich 2010: 160).

Area B also yielded 49 ceramic zoomorphic figurines and bucrania, which broadly resemble terracotta bull figurines and stone bucrania from Ona-period sites in Eritrea (Curtis \& Schmidt 2008: 95; Schmidt \& Naty 2008). Notably, Eritrean examples date to roughly a millennium earlier. It is also unexpected to find figurines and bucrania in a basilica, the presence of which suggests a mixing of pagan and early Christian traditions. One of the most perplexing finds from Beta Samati is a soft-stone pendant with incised designs and letters, recovered from just outside the eastern wall of the basilica (Figure 9). The letters found within the right-hand frame can be interpreted as Ge'ez, if one accepts that they are rotated and meant to be read in a radial pattern. In combination with the cross within the left-hand frame, the inscription reads:

$\mathrm{K}(\partial) \mathrm{B}(\mathrm{u}) \mathrm{R} \dagger$

venerable (masc.) $\dagger$, i.e. venerable cross

(C) Antiquity Publications Ltd, 2019 


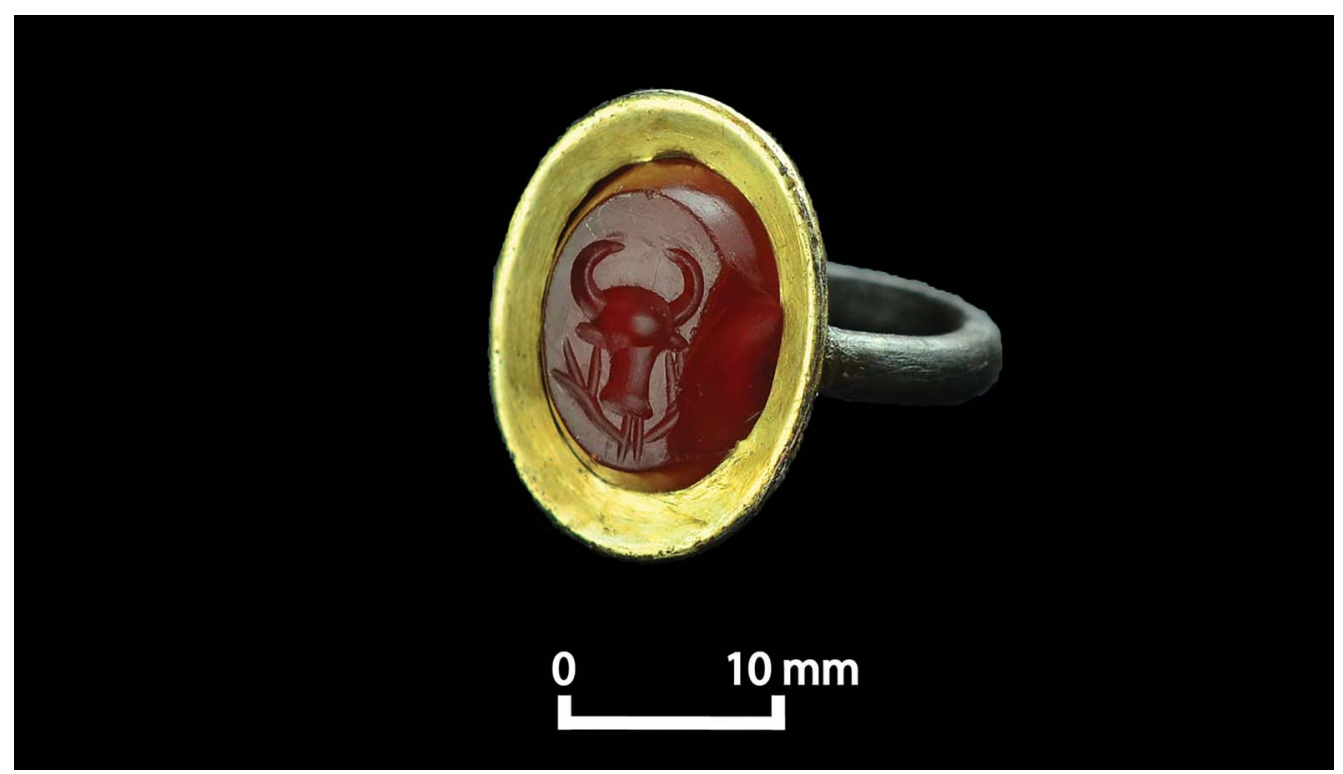

Figure 10. Gold and carnelian intaglio ring from area B (figure by I. Dumitru).

This object is clearly important in terms of ancient Christian iconography, and a more detailed analysis will be published elsewhere.

A gold bezel and carnelian intaglio ring (Figure 10) was discovered $90 \mathrm{~mm}$ below the level of the stone-paved floor, in the gap between the floor and wall B. A radiocarbon assay on a nearby wood-charcoal sample (Table 2: 6) tentatively dates the ring to the Late Aksumite period. The ring is made of copper alloy with a gold foil covered bezel and an electrum band. The intaglio is engraved with the image of a bull's head above a vine or wreath. Comparanda from Aksum include a chert intaglio, which was probably meant to be suspended rather than set in a ring, and a Roman carnelian intaglio for a ring from Ona Nagast at Aksum (Phillipson 2000: 155-56; Bard et al. 2014: 305). Although the composition of the Beta Samati ring suggests Roman influences, its iconography differs; further analyses are required to determine its origins. Although few artefacts were found in direct association with the ring, an Aqaba amphora sherd uncovered nearby recalls the importance of long-distance trade.

Fragments of semi-translucent green glass from area B appear to be from goblets that are similar to those found at Aksum (Phillipson 2000: 77-82). Evidence of glass production at Aksum (Manzo 2005; Hagos 2011), along with glass wasters from Beta Samati (area A) contradict the traditional interpretation of glass as an imported material, and further indicate Beta Samati's role in the production and trade of luxury goods.

Faunal remains from area B (NISP $=6099)$ include cattle, sheep, goats, chickens, camels, donkeys, dogs, dik-dik, antelope (Antilopinae), guinea fowl and francolin. Cattle are the most frequently represented species ( 55 per cent), followed by sheep and goats ( 41 per cent). The greater frequency of cattle in area B relative to area A suggests that, as higher-value animals, they were more readily available to elites associated with the basilica, or perhaps were served (C) Antiquity Publications Ltd, 2019 
during communal dining on special occasions (Kaplan 2008). The majority of the bones from domestic species in area B come from meat-bearing limb elements, further indicating differential access to more valuable cuts of meat between the two areas. As in area $\mathrm{A}$, the frequency of camels (NISP $=1)$ and donkeys (NISP $=3$ ) in area B is low, but nevertheless confirms the presence of these animals at the site.

In terms of plant remains, area B has yielded evidence for final-stage food preparation, without the initial processing (grinding) apparent in area A. The relatively high prevalence of charred seeds (Poaceae), along with patches of ash, ceramics and faunal remains, collectively indicate large-scale food preparation and consumption in or near area B.

Area B yielded 490 lithics, most of which are of quartz ( 43 per cent) or obsidian (33 per cent), followed by chert, chalcedony and quartzite. The 24 cores are dominated by bipolar obsidian cores (29 per cent), with some single and multiple platform cores made of quartzite or chert. The debris from area B (79 per cent) is predominantly comprised of direct percussion flakes, blades and fragments (89 per cent), along with small obsidian bipolar flakes and flake fragments (11 per cent). The 27 shaped tools (6 per cent) are mostly small obsidian backed crescents, followed by chert side and end scrapers ( 1 per cent), and one outil ecaille. Given that lithics are generally rare in the vicinity of monumental Aksumite buildings (Phillipson 2009: 128), substantial quantities in area B suggest, along with the flora, fauna and ceramics indicative of food consumption, that domestic activities were associated with, or occurred in close proximity to, the basilica.

\section{Discussion}

Beta Samati offers important new insights into Ethiopia's ancient, complex societies. Although more investigations are required to unravel the intricate history and interconnections of the site, our results suggest continuity, rather than disconnection, between the PreAksumite and Aksumite periods, albeit with few Proto-Aksumite sherds recovered thus far. This finding contradicts prior assertions that the Kingdom of Aksum represents a major political disjuncture following the abandonment of the Yeha region (Fattovich 2010, 2018). Our excavations at Beta Samati, and survey of the Yeha region (Harrower et al. in press), reveal a landscape occupied from Pre-Aksumite to Late Aksumite times. The size of the site, its location on a route connecting the Red Sea and Aksum, its iconography and the presence of luxury items indicate that Beta Samati occupied a well-connected position within the region's socio-political and economic structure.

Beta Samati is also beginning to help clarify the nature of Aksumite political/religious authority. As an architectural form, the basilica emerged in the Classical Mediterranean as a secular space used for public gatherings, financial activities, and civic and legal administration (Walthew 2002; Peirano 2018). In Ethiopia, the basilica form seems to have first appeared in conjunction with Christianity (Phillipson 2009; Di Salvo 2017). The basilica at Beta Samati, however, shows a complex blurring of secular trade and administration (tokens and stamp seals), pagan rituals (figurines and bucrania) and early Christian traditions (incense burners and crosses) that warrants further investigation. Additionally, the latest occupation of Beta Samati approximately coincides with the rise of Islam, raising interesting

(C) Antiquity Publications Ltd, 2019 
prospects for future research regarding the role of inter-regional political, economic and religious changes during the decline of Aksum.

\section{Conclusions}

Excavations at Beta Samati have yielded important new information about Pre-Aksumite and Aksumite societies, and ancient complex societies generally. Our findings overturn the notion that the Pre-Aksumite polity at Yeha collapsed leaving only "small rural settlements" (Fattovich 2010: 165). Conversely, we demonstrate that there was far greater continuity between Pre-Aksumite and Aksumite polities than previously recognised. Beta Samati illustrates the complex interplay of political and religious authority at an ancient town ancillary to the capital of Aksum, which was expressed and reinforced by an early basilica exhibiting a complex combination of pagan and Christian ritual paraphernalia, iconography and privileged access to luxuries traded over long distances. Future research at the site has the potential to clarify a range of topics, including the rise of one of Africa's first complex polities, the development of Aksum's trade connections, the conversion from polytheism to Christianity, and the eventual decline of the Empire of Aksum.

\section{Acknowledgements}

We thank the Authority for Research and Conservation of Cultural Heritage, Tigrai Culture and Tourism Bureau, UCLA, Aksum University, and Johns Hopkins University. A Cotsen Excavation Grant from the Archaeological Institute of America (2015) and a Committee for Research and Exploration Grant from the National Geographic Society (2016) supported excavations. We are grateful to Aley Woldeselassie, Habtamu Mekonnen, Seminew Asrat, Gidey Gebreegziabher, Gabriela Giovannone, Rachel Moy, Lucile Denizot, Fantahun Zelelew, Mekonnen Gebre-Meskel, Morgan Moroney, Tesfay Aragie and the people of Edaga Rabu and Ahferom Woreda.

\section{References}

ANFray, F. 1973. Nouveaux sites antiques. Journal of Ethiopian Studies 11: 13-27.

- 1990. Les anciens Ethiopiens: siecles d'historie. Paris: Armand Colin.

- 2012a. Le site de Dongour, Axoum, Ethiopie: recherches archéologiques. Hamburg: Books on Demand.

- 2012b. Matara: the archaeological investigation of a city of ancient Eritrea. Palethnologie 4: $11-48$.

Anfray, F. \& G. Annequin. 1965. Deuxième, troisème et quatrième campagnes de fouilles. Annales d'Ethiopie 6: 49-86. https://doi.org/10.3406/ethio.1965.1135

Bard, K.A., R. Fattovich, A. Manzo \& C. Perlingieri. 2014. The chronology of Aksum (Tigrai, Ethiopia): a view from Bieta Giyorgis. Azania 49: 285-316. https://doi.org/10.1080/0067270X.2014. 943484
Bausi, A. 2017. History of Aksum, in S. Uhlig, D. Appleyard, A. Bausi, W. Hahn \& S. Kaplan (ed.) Ethiopia: history, culture and challenges: 98102. East Lansing: Michigan State University.

Breton, J.-F. 2015. Les battisseurs des deux rives de la mer Rouge. Paris: Éditions de Boccard. https://doi.org/10.4000/books.cfee.792

Bronk Ramsey, C. 2009. Bayesian analysis of radiocarbon dates. Radiocarbon 51: 337-60. https://doi.org/10.1017/S0033822200033865

CAIN, C.R. 2000. Animals at Axum: zooarchaeological research in the later prehistory of the northern Ethiopian Highlands. Unpublished $\mathrm{PhD}$ dissertation, Washington University, St Louis.

Chaix, L. 2013. Fauna from the UNO/BU Excavations at Bieta Giyorgis (Aksum) in Tigray, northern Ethiopia. Journal of African Archaeology 11: 211-41. https://doi.org/10.3213/2191-5784-10244

Curtis, M. 2009. Relating the ancient Ona Culture to the wider northern Horn: discerning patterns

(C) Antiquity Publications Ltd, 2019 
and problems in the archaeology of the first millennium BC. African Archaeological Review 26: 327-50. https://doi.org/10.1007/s10437-009-9062-4

Curtis, M. \& P.R. Sснмidt. 2008. Landscape, people, and places on the ancient Asmara plateau, in P. Schmidt, M. Curtis \& Z. Teka (ed.) Archaeology of ancient Eritrea: 65-108. Trenton (NJ): Red Sea.

D'Andrea, A.C. 2008. T'ef (Eragrostistef) in ancient agricultural systems of Highland Ethiopia. Economic Botany 62: 547-66. https://doi.org/10.1007/s12231-008-9053-4

D'Andrea, A.C., A. Manzo, M. Harrower \& A. Hawkins. 2008a. Pre-Aksumite and Aksumite settlement of north-eastern Tigrai, Ethiopia. Journal of Field Archaeology 33: 151-76. https://doi.org/10.1179/009346908791071268

D'Andrea, A.C., P.R. Schmidt \& M.C. Curtis. 2008b. Paleobotanical analysis and agricultural economy in early first millennium BCE sites around Asmara, in P. Schmidt, M. Curtis \& Z. Teka (ed.) Archaeology of ancient Eritrea: 207-16. Trenton (NJ): Red Sea.

Di Salvo, M. 2017. Basilicas of Ethiopia: architectural history. London: I.B. Taurus.

Fatтovich, R. 1980. Materiali per lo studio della ceramica pre-aksumita etiopica. Napoli: Universitario Orientale di Napoli.

-2009. Reconsidering Yeha, c. 800-400 BC. African Archaeological Review 26: 275-90. https://doi.org/10.1007/s10437-009-9063-3

-2010 . The development of ancient states in the northern Horn of Africa, c. 3000 BC-AD 1000: an archaeological outline. Journal of World Prehistory 23: 145-75. https://doi.org/10.1007/s10963-010-9035-1

-2018 . From community to state: the development of the Aksumite polity (northern Ethiopia and Eritrea). Journal of Archaeological Research 27: 249-85. https://doi.org/10.1007/s10814-018-9122-x

Finneran, N.J. 2007. Archaeology of Ethiopia. London: Routledge.

GerLach, I. 2012. Yeha: an Ethio-Sabaean site in the Highlands of Tigray (Ethiopia), in A. Sedov (ed.) New research in archaeology and epigraphy of South Arabia and its neighbors: 215-40. Moscow: Ministry of Culture.

Hagos, T. 2011. Archaeological excavations at the church of Arbaetu Ensesa, Ethiopia. Annales
d'Ethiopie 26: 79-98. https://doi.org/10.3406/ethio.2011.1432

Hahn, W. 2010. Sequence and chronology of Late Aksumite coin types. Journal of the Oriental Numismatic Society 205: 5-10.

Harrower, M.J., S. Nathan, J.C. Mazzariello, K. Zerue, I.A. Dumitru, Y. Meresa, J. Bongers, G. Gebreegziabher, B.F. ZaitchiK \& M.C. Anderson. In press. Water availability and the empire of Aksum: the Southern Red Sea Archaeological Histories (SRSAH) project survey (2009-2016). African Archaeological Review.

HatKe, G. 2012. Holy land and sacred history: view from early Ethiopia, in W. Pohl, C. Gantner \& R. Payne (ed.) Visions of community in the post-Roman world: the West, Byzantium and the Islamic world, 300-1100: 259-75. London: Routledge.

- 2013. Aksum and Nubia. New York: New York University Press.

Heldman, M. 2003. Churches, in S. Uhlig (ed.) Encyclopaedia Aethiopica, volume 1: 737-40. Wiesbaden: Harrassowitz.

Kaplan, S. 2008. Finding the true cross: the social-political dimensions of the Ethiopian Mäsqäl festival. Journal of Religion in Africa 38: 447-65. https://doi.org/10.1163/157006608X375057

Krencker, D. 1913. Deutsche Aksum-Expedition, Band II. Berlin: Georg Reimer.

Lyons, D. 2007. Integrating African cuisines: rural cuisine and identity in Tigray, Highland Ethiopia. Journal of Social Archaeology 7: 346-71. https://doi.org/10.1177/1469605307081393

Manzo, A. 2003. Note sulla più antica fase archeologica Aksumita. Rassegna di Studi Etiopici 2: 37-50.

- 2005. Aksumite trade and the Red Sea exchange network: a view from Bieta Giyorgis (Aksum), in J.C.M. Starkey (ed.) People of the Red Sea: 51-66. Oxford: Archaeopress.

- 2009. Capra nubiana in Berbere sauce? Pre-Aksumite art and identity building. African Archaeological Review 26: 291-303. https://doi.org/10.1007/s10437-009-9066-0

Michels, J.W. 2005. Changing settlement patterns in the Aksum-Yeha region of Ethiopia: $700 B C-A D$ 850. Oxford: Archaeopress.

Munro-HaY, S. 1995. A new gold coin of King MHDYS of Aksum. Numismatic Chronicle 155: 275-77.

Munro-Hay, S. \& B. Juel-Jensen. 1995. Aksumite coinage. London: Spink. 
PeIrano, D. 2018. Internal arrangements in some early Christian basilicas of the Eastern Mediterranean. Hortus Artium Mediaevalium 24: 162-70. https://doi.org/10.1484/J.HAM.5.115945

Phillipson, D.W. 2000. Archaeology at Aksum, Ethiopia, 1993-7. London: Society of Antiquaries.

- 2012. Foundations of an African civilization: Aksum and the northern Horn 1000 BC-AD 1300. Woodbridge: James Currey.

Phillipson, L. 2009. Using stone tools: evidence from Aksum, Ethiopia. Oxford: Archaeopress.

Raith, M.M., R. Hoffbauer, H. Euler, P.A. Yule \& K. DamgaArd. 2013. The view from Zafar: an archaeometric study of the Aqaba pottery complex and its distribution in the $1^{\text {st }}$ millennium CE. Zeitschrift für Orient-Archäologie 6: 320-50.

Reimer, P.J. et al. 2013. IntCal13 and Marine13 radiocarbon age calibration curves $0-50000$ years cal BP. Radiocarbon 55: 1869-87. https://doi.org/10.2458/azu_js_rc.55.16947

Ricci, L. \& R. Fattovich. 1987. Scavi Archeologici nella Zona di Aksum. B. Bieta Giyoorgis. Rassegna di Studi Etiopici 31(2): 123-97.
Robin, C. \& A. de Maigret. 1998. Le Grand Temple de Yéha (Tigray, Éthiopie), après la première campagne de fouilles de la mission Française. Comptes-rendus des seances de l'Academie des Inscriptions et Belles-Lettres 142: 737-98. https://doi.org/10.3406/crai.1998.15906

Schmidt, P.R. \& A. NAty. 2008. Bulls' heads and enigmas: strong inference and interpretive puzzles in Eritrea, in P.R. Schmidt, M.C. Curtis \& Z. Teka. Archaeology of ancient Eritrea: 235-46. Trenton (NJ): Red Sea.

Schmidt, P.R., M.C. Curtis \& Z. Teka. 2008. Archaeology of ancient Eritrea. Trenton (NJ): Red Sea.

van Donzel, E. \& G. Schoeler. 2007. Hiğra, in Encyclopaedia Aethiopica, volume 3: He-N. Wiesbaden: Harrassowitz.

Walthew, C.V. 2002. A metrological study of the Early Roman basilicas. Lewiston (NY): Edwin Mellen.

Zazzaro, C. 2013. The ancient Red Sea port of Adulis. Oxford: Archaeopress.

Received: 7 December 2018; Revised: 3 May 2019; Accepted: 20 May 2019

(C) Antiquity Publications Ltd, 2019 